\title{
Problem in Patient Information System Acquirement in Finland: Translation and Terminology
}

\author{
Minna Rantanen and Olli I. Heimo \\ University of Turku, Turku, Finland \\ \{mimaran, olli.heimo\} @utu.fi
}

\begin{abstract}
Healthcare information systems and their development has risen to be an issue discussed widely amongst Finnish media and public. The discussion varies from the many faults in design, functionality, usability and the enormous costs these systems produce to the citizens as well as how to best fix these problems. Yet it seems that common terminology with eHealth systems in the discussion is lacking rendering the quality of the discussion far from where it could be. Hence this paper will focus on the issue of terminology-based problems in Finnish public eHealth development discussion.
\end{abstract}

Keywords: Information Systems, Healthcare, eHealth, Terminology, Healthcare Information Systems.

"[I]t is probably unwise to try to define the EMR [Electronic Medical Records] in any form or way. It is more fruitful to observe that there are range of clinical activities that use and communicate information, and that some of these can be supported through the introduction of technology." - Enrico Coiera [1]

\section{Introduction}

In this paper we discuss about the lack of clear definition both in Finnish and English research and teaching materials concerning Healthcare Information Systems (HIS). This lack of definition - which we will later demonstrate - creates rather curious and obviously unwanted situations to the society which may hinder the efficiency of the eHealth IS development process nationwide. First of all, the problem lies within the varied terminology in both English and Finnish.

In this context - due the lack of better term - we have translated the commonly used Finnish term "Potilastietojärjestelmät" as Patient Information Systems (lit., later PIS), whereas electronic patient records (EPR) and electronic medical records (EMR) are more commonly known terms used as the translation. Word "record" does not capture same amount of functionality that "information system" does. The term PIS is used in this paper as a one-time definition to clarify the Finnish-English 
translation and the Finnish discussion and is not necessarily meant for common use at least without careful consideration and discussion. The paper will focus on this problem in both translation and terminology in Finnish patient information system acquirement.

In next chapter the Finnish healthcare and eHealth areas are introduced. In third chapter the problems concerning the lack of common language are discussed. The reasons to focus for the aforementioned problems are briefly discussed in fourth chapter and fifth chapter introduces the current at-hand definitions and their contradictions with each other. The discussion about how these thing should be developed are analysed in sixth chapter.

\section{$2 \quad$ Finland and eHealth}

Finland differs as an area for eHealth solutions from many countries. As being a North European welfare state, Finland offers almost free medical services to its inhabitants (only minor fees) and participates on the payment of medicines prescribed by medical doctors. One of the key areas that limit the competition in Finnish eHealth market is the language support which is required in both Finland's official languages: Finnish and Swedish (which in larger scale are both minority languages not worth the trouble for many international eHealth software and hardware providers).

In Finland healthcare service is a basic right for every citizen and it is divided into two sectors: public and private. Public healthcare is funded by counties and the state of Finland. Funding is acquired in a form of public medical insurance and small clinical fees. Private healthcare is more expensive but citizens can apply for compensation from state when using these services. Finnish employers are required to pay for healthcare of their employees in private healthcare sector but the patients are often transferred to public healthcare to receive more complex treatment. Every citizen is part of healthcare system even before they are born. Therefore decisions in public healthcare information systems concern every citizen.

In healthcare information systems the scene is dominated by Tieto Oyj (former TietoEnator) c.a. $49 \%$ and CGI (former Logica) with c.a. 30\% of public healthcare market share. While the eHealth scene in Finland has internationalized, new actors in the market have not been found but moreover the local business' have gone international, e.g. Tieto Oyj, or international companies have bought local ones, e.g. CGI. [2, $3,4]$.

Patient information systems have been a subject of both public and professional discussion in Finland of late due to the government and its healthcare districts having procured numerous different PISs, latest of those being Helsinki and Uusimaa Healthcare district's Apotti program (see [5] and e.g. [6, 7, 8, 9, 10, 11]). Apotti's latest cost approximation is 162300000 euros and yearly costs 77900000 euros [12] which raised quite active discussion about the price and requirements of these systems. Yet it seems that a proper discussion is impossible due the differences in both translation and in terminology: we do not have a definition for PIS. Also healthcare 
information system is a commonly known term, but with its larger scale: all HISs are not PISs.

Thus in this paper the term eHealth is used as for all electronic healthcare systems; Healthcare Information Systems (HIS) as all information systems in healthcare sector (consisting everything from eHealth except the medical machines that are not exactly information systems for example Therac-25); EPR, EHR and EMRs as registries without proper functionalities and PIS as Patient Information System - a system that is a Healthcare Information System consisting on patient information and focusing on treating patients. In our definition HIS can be an EPR, EHR or EMR, PIS, or e.g. an online medical guide.

On international scale, Oh, Rizo, Enkin and Jadad [13] found similar problems concerning the definition of eHealth and similar problem has also been addressed by Häyrinen, Saranto and Nykänen [14] about Electronic Health Records (EHR). None the less they did not produce exact solutions to the research question we tackle in this paper - quite the contrary. We argue that the discussion around the subject of PIS in Finland seems to be more like Plato's Theory of Forms (see [15]), where the idea of a PIS should be in the mind of everyone.

\section{The Problem}

Yet the Theory of Forms is not a proper tool to discuss about something as complex as patient information systems. Whilst the idea of a horse or a chair might be common for most of us, the idea of a specialised information system is more dependent on who reflects it to the real world. Whilst an engineer can see the problem as a technical one, a sociologist or economist has quite a different view about the subject. Therefore whilst the reflected idea is subjective, we need something more clear to have a discussion upon.

The information system viewed in larger context consists of not only the technology nor the communications of the actors within the technology, but actually from any communication and delivery of information between the actors in real time or in stored format for their work tasks. Thus, the information system can consist of two persons just talking or from a nation-wide or international discussion boards, factory management systems etc. [16]

In this context the healthcare information systems are not only electronic patient records, electronic health records (EHR) nor computerised patient records (CPR), but much more. Therefore, according to Nurminen [16], a HIS is a combination of software, electronics, papers, doctors, nurses and patients, their stored data, knowledge and communication. Thus the topic, patient information systems, are not only technical problems nor solutions and they should not be viewed as such, but instead as a complex combination of workers and their tools flavoured and tied together with the communication between them. Yet, it sometimes seems that the technical and economical decisions seem to dominate both the discussion and the acquirement process (see e.g. $[6,7,8,9,10,11,17,18,19,20,21,22]$ ). 
Language problems seem to be a relevant factor in public discussions. While it seems that scientific discussion in English concerning different eHealth solutions is carried out with many different terms and in research these are used in contradiction with each other (see e.g. [13, 23]) the translation to Finnish makes it even worse. When the English terms are translated to Finnish, the translations themselves are in contradiction with each other (e.g. EPR can be translated a number of different ways). This contradiction in contradiction is obviously not a double negative.

Finnish Foundation of Nursing Education provides an online nursing dictionary Hoidokki which translates "potilastietojärjestelmät" as "medical records systems" (MRS) [24]. Other translation can be found from the Apotti Program, where the term is translated as "patient data system" [25] and Finnish researchers use terms such as "electronic patient record" (see e.g. [26]) in their English abstracts. Thus a common translation cannot be found. Problem with EMR's translation is that it represents only the database used to store medical information. Information systems are far more complicated than that.

Whereas the records are mere storages of data, information systems contain numerous functions. Records can be viewed as an archive, a set of papers, while the information system consists of both the papers and the people storing, reading and creating them. Even though Garets and Davies [23] describe EMR as application environment which consists of many different parts, EMR does not translate to Finnish as 'patient information system'.

Yet the definition is not a dilemma only for Finns, but indeed part of a larger, international problem. The terms EMR and EHR are used as a representation of the same thing even though EMR includes data about how patient has been treated. In comparison, one EHR is a subset of EMR, which is derived from this information e.g. for healthcare decisions concerning whole healthcare system. [23]

Healthcare information systems seems to be the most comprehensive term covering all information systems used in healthcare. Thus all patient information systems are healthcare information systems but - as mentioned before - not all HISs are PISs. In this context though, the patient information system seems to be the most accurate translation for "potilastietojärjestelmät" and represents the context in which the term is used in.

PISs are rarely defined in any Finnish researches even if they are the subject of research. For example articles published in Finnish Medical Journal assume that the term is commonly known [27, 28]. When the term is discussed, definitions are often vague and superficial such as "PISs are information systems that save, store and transport patient information [29]. It might not be a problem that defining PIS is deliberately avoided because too many definitions can and are problems in health informatics as well.

Terms such as eHealth are defined in too many ways to understand what they really mean. [13] Making up definitions for the purpose of making up definitions does not solve the problem; quite the contrary, numerous different definitions make discussion harder because - yet again - the common language is missing. Since too many definitions for one term an easily identified problem, definition of PIS should be discussed 
carefully and not to be taken into use hastily - if at all. Any useful definition should be widely accepted and coherently used.

How people perceive PIS depends strongly on their role in healthcare. For the doctors and nurses PISs are daily used tools whereas economists view them from monetary perspectives. In Finnish media discussion about PISs has been especially focused on poor usability, information security and money (see e.g. [7, 8, 17, 18, 19, 20, 21, 22]). This shapes the conception of PISs in the minds of people that do not know much about topic. While the discussion is strongly focused on making better PISs and eHealth solutions in general, the public has limited ability to participate into the discussion partly due to lack of proper terminology. When this is enforced with the lacking of proper terminology from the professionals, the discussion turns limited towards not only the public but the whole society consisting of the professionals in different areas. Even if they would like to form a neutral concept or at least a form about PISs it is almost impossible since PISs are not defined in any easily findable sources. It can only be imagined how confusing this lack of information is for average patients since it is hard even for scientists researching the subject.

Since the definition of PIS depends strongly on a person it is impossible to have understandable public conversation about the subject that can include and empower everybody - or anybody - in Finnish society.

Koskinen, Heimo and Kimppa [30] argue that healthcare information systems (HIS) should be built not only to computer ethics, but especially to medical ethics to support the work process the information system is an inseparable part of. They extend the thought to the limit that medical ethics should be used as a common language of on what basis the information system should be built. The idea is more refined in an article by Heimo, Kimppa and Nurminen [31] to the extent that the information systems, work process and the ethical basis of both are inseparable from each other. In addition, we argue that the language, the used terminology, seems to be inseparable from the information systems and the work process they support.

Heimo, Koskinen and Kimppa [32] argue for a public (Habermasian) discourse to be used as a tool for developing information systems. Although this discourse could be - as the authors proclaim - important indeed, in the case of HIS procurement in Finland in its current state it is irrelevant. Without a common language the Habermasian discourse could not even start for its premises are not met. Thus if the Habermasian discourse or any other form of discussion is a part of the solution in procuring, the terminology should be standardised.

\section{Healthcare Information Systems as a Critical Service}

Due to the promotion of the health and wellbeing in the society, Healthcare Information Systems are a critical service to the patients. In countries like Finland (this case) where the basic medical care is arranged by the government, it can also be counted as a Critical Governmental Information System, and thus it has some 
similarities with other CGIS and thus while developing a CGIS, certain additional features to the development must be taken into account to minimize the amount of undesired consequences.

Heimo et. al. [32] define Critical Governmental Information Systems (CGIS) as following:

"A critical governmental information system (CGIS), by definition, is an information system developed for governmental needs including data or functionality which is critical in nature to the security or wellbeing of individuals or the society as whole. It is a system where something invaluable can easily be compromised. These kinds of systems include eHealth, eDemocracy, police databases and some information security systems e.g. physical access right control."

Numerous case-studies show that due poor eGovernment solutions lives have been lost. The most classic example in the field is the case London Ambulance Dispach System, where due to the new information system ambulances were sent to wrong targets, causing several deaths and injuries [33, p. 292-293 ]. Other examples include the usage of THERAC-25 radiation treatment machines which caused at least six deaths [34] and numerous eVoting solutions, where elections have been compromised numerous times worldwide [35, p. 13-20, 36, 37].

Massive amounts of pre-allocated resources [38] are wasted while the systems are either inoperable or end up being discarded [30, 36, 39, 40, 41]. Thus, when countries have been developing CGISs, the room for errors has been exceeded.

In healthcare even the most valued thing - life itself - has its price. When the resources allocated are not limitless, some medical devices, some medications and some treatments cannot be paid - i.e. some people are not treated while others receive their treatment. When the aforementioned resources, that is money and work effort, are being used carelessly, people needlessly lose their access to their own health and wellbeing - as well as to their life. Therefore there should be no question should these things be taken with utmost importance. Moreover, if the acquirement of these information systems should be done virtuously (see Aristotle), that the system itself would be a virtuous one, it must be done with the best quality possible keeping the purpose of the system - health and wellbeing of the citizens - in the centre of the acquirement from the beginning [42] ${ }^{1}$.

Thus the government-acquired healthcare information systems are of great importance to the Finnish public. Whereas a citizen can choose whether or not to use the services of a certain private medical service provider, usually their only option with public healthcare is to use the services or to suffer. Thus the public discussion of how the citizens - the possible patients - should be treated is (and as it should be) a matter of clear importance to the whole society.

\footnotetext{
${ }^{1}$ NE 1096a10-1098b10.
} 


\section{Definitions and Their Contradictions}

The field of healthcare is a field of specialization, divided to various different fields of the medicine all having their own special requirements for IS. That IS must support the work processes and procedures in a very fragmented healthcare system. Thus, many of the problems with eHealth systems, in addition to the other problems in IS development in general, mostly lie within this typical fragmentation of healthcare [30, 43]. Yet it seems that if the information system cannot be built on ethical basis supporting the healthcare [30] or if the terms and definitions are not common the system cannot fulfil its requirements.

While the field of healthcare is fragmented, so is the field of healthcare information systems. During the 1960s hospital information system developers in Finland were mainly doctors and amateurs that were interested in making healthcare more efficient. Hospitals developed their own individual systems and cooperation especially in the beginning was rare. Already in the early days the government was funding system development and soon noticed increasing costs of development. Cooperation was soon demanded and the power to direct the development was given to big hospitals. Biggest change in terms of hospital system development occurred in 1990s when counties were made responsible for funding majority of their costs. Counties started to purchase their own systems and information systems were evaluated by their potential efficiency and ability to save money. [44, p.11-30, 45, p. 63-85.]

This led to the current situation where both public and private sector have been fragmented information system wise. Many different PISs and versions of them are been used. PISs have been strongly customized to meet the needs of every healthcare units individually. Thus, it is challenging to define the basic body of PIS locally - and international community is yet to give the Finnish discussion much-needed aid due to the problems in defining terms like eHealth and EHR [13, 14].

It appears that PIS can include any subsystems that have something to do with patient information or taking care of patients. Because the main task of hospitals is taking care of patients, many of their systems are - or at least should be - supporting that process and be somewhat involved in handling the patient data. As mentioned not all PISs are HISs although it is hard to separate them. If information systems are viewed as social-technological systems instead of only technological system (see e.g. [16]), it could be argued that every person working with patients or handling their data is part of PIS.

In Finnish nursing literacy few attempts to define PIS have been made. According to Mäkelä [44, p. 63] PIS is "very wide and diverse software and database compilation that contains all information related to patients health and treatment" and "PIS connects patient information to another information in healthcare".

Mäkelä's definition is based on the idea that patient information makes PIS whereas Korpela and Saranto [46] aim to define PIS through the structure. They divide systems into core system and unit-based separate systems [46, p. 25]. According to them, the core systems are systems that handle patient information in comparison to the separate systems that are laboratory systems and such non-patient-information focused systems. This seems not to clarify the concept of PIS enough. 
As another example of vague definitions, SITRA [A Finnish Innovation Fund] define the patient information systems as following:

"Patient information system is formed from one or more base system functional units which create functional unit healthcare services and together form a functional unit patient information registry (Arkkitehtuurimääräyssanasto 2007 [unavailable reference]). Patient information systems are e.g. EPR, communication system between hospital and laboratory, radiological image delivering and communication system, healthcare area's information system and image archive."2 [47].

The aforementioned quote is a good example of a definition concerning patient information systems. Not only is it in contradiction with other definitions, but it also lacks a proper definition: while the examples give the reader some image of what the writer has been trying to describe, the term 'functional unit' has as little meaning in Finnish as it has in English.

One part of this research was an e-mail survey for the people in close encounter with PISs such as governmental units, providers of PISs and healthcare districts etc. Surveys contained only one simple question: "How do you define patient information system?" but several of these queries turned out to be e-mail discussions. These original e-mails were sent to Ministry of Social Affairs and Health (STM), Minister of Social Affairs and Health, Finnish National Institute for Health and Welfare (THL), National Supervisory Authority for Welfare and Health Valvira, Accenture, CGI, Tieto Oyj and The Hospital District of Helsinki and Uusimaa and The Hospital District of Southwest Finland. On top of that survey was sent personally to politicians who are or have been discussing PISs within the last few years in Finnish media. The received information was combined with the literature review concerning eHealth solutions.

All the definitions gathered were in contradiction with other definitions. In addition, majority of people who answered the question acknowledged the lack of unanimous definition for Finnish. Only the representative of National Supervisory Authority for Welfare and Health Valvira was sure of the definition and that it has been made and clarified. The aforementioned representative believed strongly that the Finnish law defines PISs clearly enough. He also argued that definition can be found in certain Internet site, although this information was found to be incorrect. Valvira equates PISs with healthcare devices, such as blood pressure monitors and they claim they do not handle definitions but only legal requirements.

Also the preference in using term electronic patient record instead of PIS because of lacking definition came forth during the interviews. In this case tough, as

2 "Potilastietojärjestelmä muodostuu yhdestä tai useammasta toimintayksikön perusjärjestelmästä, jotka tuottavat toimintayksikön terveydenhuoltopalveluja ja yhdessä muodostavat toimintayksikön potilasrekisterin (Arkkitehtuurimäärityssanasto 2007). Potilastietojärjestelmiä ovat esimerkiksi potilaskertomusjärjestelmä, laboratorion lähete- ja lausuntojärjestelmä, radiologisten kuvien lähete- ja lausuntojärjestelmä, terveydenhuollon aluetietojärjestelmä sekä kuva-arkisto." 
mentioned before, using different term e.g. EPR does not answer the question or solve the problem because it is far too narrow term like previously mentioned EMR. THL representative had in the past tried to define term PIS with her colleagues. Their definition is that "PIS is information system that is meant for saving and handling patient information" [29].

The amount of different answers to this simple question - and the lack of (clear) answers - showed that the lack of definition is truly a problem. Organizations such as the Ministry of Social Affairs and Health (STM) should have a clear idea what a PIS is, but none of their representatives responded to survey. Even the answers from politicians repeatedly presenting ideas about PISs were lacking. This raises the question about their knowledge about PISs? It seems clear enough that many of these people know that the definition is lacking but only two of the whole set of participants showed interest for the existence of a proper definition. Does this mean that terminology is considered useless or is the question too hard to answer?

As shown before, it seems that no common terminology seems to be found within Finnish eHealth discussion. While the question of the definition of different eHealth terms - when arisen - should at least arise some interest, its importance to the people participating to the discussion seems to vary. This raises an alarming thought: if people are not interested in having a common terminology, are they having the discussion for other purposes than to develop the PIS in best way possible? In any case, this seems to be a matter to be fixed.

\section{How Patient Information Systems Can Be Defined?}

As mentioned before, instead of being considered as a stand-alone system PISs can be thought as a compilation of various systems and actors. Systems used in healthcare units vary according to their particular needs and thus is hard to define what typical PIS is and more, what subsystems are of PIS and what are not. Patient information is - or at least should be - the center of any PIS and it connects many systems together.

Treatment for health and wellbeing of the citizens is the process that is in common with all of these systems because for example treatment regulation dictionaries are also part of PISs. Thus it can be said that current PISs contain systems that support patients treatment process via information as well as many other subsystems directly or indirectly connected to the aforementioned process. These subsystems can include e.g. EMR, billing and ledger information, customer service www-portal, delivery room special services and service providence monitoring. [48, 49].

As mentioned in previous chapter: THLs definition of the PIS is "a system meant for saving and handling patient information." This seems to be a quite broad definition not really clarifying the term. As noted before, information systems can be people knowing and communicating verbally or via pieces of paper to large computerised systems. If we use this definition, all of the hospital staff that handle patient information in some way are part of PIS. What are the computerised parts of PIS?

Apotti program has so far been a somewhat public project. The planned infrastructure of the future system has been published. The system has been divided into two 
parts: core and integrated systems. The core systems include for example client and patient records, systems for controlling them and information about treatments and services. The systems are directly involved with patient care taking process. Also, the patient data is used for billing information, but this is not a crucial part of the process. [49]

Integrated systems are systems of specialized medical healthcare units and other systems which are involved with patient data but not in same amount as previously mentioned systems. For example laboratory systems are integrated systems.

Other PISs are like puzzles that have been put together accounting to healthcare units' needs. Which puzzle pieces the units have selected remains largely a mystery. PISs are collections of subsystems that use patient data in particular unit of healthcare. (e.g. [47].)

One approach could be the approach of functionalities and their levels of importance. While client and patient records, medication control and log data are obviously core functions in any PIS solutions, it can be argued that billing is not. This obviously leads to certain problems not the least being the subjective requirements from the system from different interest groups. E.g. a hospital could not fund its functions long, if it could not do billing. Therefore more than mere functionalities must be the key for the definition.

Another method for defining is an approach from the content. The most important information within the PIS is the patient information. The main goal of storing patient information is to give access to patient information. With this approach though PISs and EMRs, EHRs and EPRs can easily be equated with each other.

Third method for defining could be the definition through the structure, i.e. through the analysis of sublevels of the system. This seems to be the main definition method used to define Apotti system. Through this method patient information system could consist from various different systems with some overlapping functionalities. The sublevels could be patient information systems themselves, but they also could be mere EMRs, databases, registries or actors. In Apottis case the PIS can be defined to contain the core functions (see [49]). This, although clarifying definition, seems to be a case-specific method which always requires another method to support the definition.

Fourth method - and the most used method - is through examples and negations. With this method examples of PISs and non-PISs are delivered for the explanation and definition of a PIS. Although being the clearest of the methods available yet, this method suffers from the similar problems than the aforementioned Theory of Forms.

Therefore it seems that there is no easy way out of this yet important dilemma and it seems that a good and exact definition requires more analysis. While the approximate idea could be delivered from the aforementioned directions a usable - or even a more defined - idea still requires more analysis and discussion. Our future research will concentrate on the combination of the methodologies in defining the terminology more accurately within both national and international contexts. 


\section{Conclusions}

As shown above, it seems that little common language exists in Finnish healthcare information system development discourse. Due to the lack of proper and meaningful discussion the problems not only appear as a linguistic one but yet a problem in the whole acquirement process of procurement, development, implementation and upkeep.

Due to the difficulties in defining eHealth [13], EHR [14] or the defining of PIS, it can be presumed that this problem is not unique to Finnish discussion but also exists in other countries. The global terms as well as the localised terms should be made if not unambiguous at least understandable.

To have a discussion with one another we require a common set of terms understood by everyone. To develop complex multidisciplinary information systems we need a possibility for discussion. To enhance our level of healthcare we require complex multidisciplinary information systems. Thus, the further development of terminology in the subject is not only recommended but required.

Therefore our future research on the topic will focus on more defined glossary concerning patient information systems and other healthcare information systems so that public discussion about the subject will have a possibility to flourish.

\section{References}

1. Coiera, E.: Guide to health informatics, 2nd edn. Oxford University Press Inc., New York (2003)

2. THL (National Institute of Health and Wellfare): KanTa-palvelut: Kansallinen potilastiedon arkisto Alustava käyttöönottoaikataulusuunnitelma v.2.2 (November 11, 2013) (Kanta services: National archive of patient information Preliminary implementation plan v.2.2.) (2013), http: / /www. kanta.fi/documents /12105/3494314/

Potilastiedon+arkisto_suunnitelma+k\%C3\%A4ytt\%C3\%B6\%C3\%

B6nottoaikatauluista_v+2+2.pdf/c490ae41-1c4e-4fc1-bc9d-

4b841c3e753f (accessed January 6, 2014)

3. CGI: Historia: CGI:n tarina Suomessa (History: CGI's story in Finland) (2014), http: / /www.cgi.fi/historia-suomessa (accessed January 6, 2014)

4. Tieto: Historia (History) (2014), http://www.tieto.fi/tiedosta/historia (accessed January 6, 2014)

5. City of Helsinki: APOTTI-hanke usein kysytyt kysymykset(APOTTI Program FAQ) (2013), http: / /www.hel.fi/hki/apotti/fi/Apotti-hanke/FAQ (accessed: December 23, 2013)

6. Helsingin Sanomat / Tuomas Peltomäki: Uutisanalyysi: Apotti-hanke saa maksaa tietotekniikan vanhoista synneistä (News analysis: Apotti programwillpay for the oldsins of computing) (September 12, 2012),

http: / /www.hs.fi/kotimaa/a1347361544072 (accessed January 3, 2014)

7. Helsingin Sanomat / Esa Juntunen: Apotti-järjestelmä tulee kaikkien kukkarolle (Apotti systemwillbeexpensive for everyone) (August 26, 2013), http: / / www.hs.fi / kaupunki / a1377399301286 (accessed January 3, 2014)

8. Kasvi, J.J.J.: Blog entry: Apotinsynti (The sin of Apotti) (January 26, 2013), http: //jyrkikasvi . puheenvuoro.uusisuomi.fi/131025-apotinsynti (accessed January 3, 2014) 
9. Tietokone / Seppo Lindstedt: Apotti-hankevaatiitehohoitoa (Apotti Program needs intensive care), http://www.tietokone.fi/artikkeli/uutiset/apotti_ hanke_vaatii_tehohoitoa (accessed January 3, 2014) (March 14, 2013)

10. YLE (Finnish National Broadcasting Company) AnnamariIranto: Apottijärjestelmäkehittyyvuorovaikutuksessa (Apotti system is being developed in interaction), http://yle.fi/uutiset/apotti-jarjestelma_kehittyy_ vuorovaikutuksessa/ 6633702 (accessed January 3, 2014) (May 8, 2013)

11. IT-Viikko / Perttu Pitkänen: Viron potilasjärjestelmän kehittäjä pilkkoisi HUS:in Apotin osiin (The Estonian patient information system developer would modularise Apotti) (May 30, 2013), http://www.itviikko.fi/uutiset/2013/05/30/vironpotilasjarjestelman-kehittaja-pilkkoisi-husin-apotin-osiin/ 20137634/ 7 (accessed January 3, 2014)

12. City of Helsinki: Apotti-järjestelmän kustannushyötylaskelma (Cost-benefit calculation of Apotti-system) (2013),

http://www.hel.fi/static/taske/apotti/asiakas-ja-

potilastietojarjestelman-kustannushyotylaskelma-2013.pdf (accessed: January 3, 2014)

13. Oh, H., Rizo, C., Enkin, M., Jadad, A.: What Is eHealth (3): A Systematic Review of Published Definitions. Journal of Medical Internet Research (February 2005),

http://www.ncbi.nlm.nih.gov/pmc/articles/PMC1550636/

(accessed: December 20, 2013)

14. Häyrinen, K., Saranto, K., Nykänen, P.: Definition, structure, content, use and impacts of electronic health records: A review of the research literature. International Journal of Medical Informatics 77(5), 291-304 (2008)

15. Plato ( $380 \mathrm{BC})$, The Republic. Multiple translations

16. Nurminen, M.I.: Kolme näkökulmaa tietotekniikkaan (Three perspectives on information technology). WSOY (1986)

17. Helsingin Sanomat / Karoliina Liimatainen: It-järjestelmän tilaaminen on taitolaji (Ordering information technology systems is skill based),

http: / /www.hs.fi/talous/a1378456580086 (accessed January 6, 2014) (September 7, 2013)

18. Helsingin Sanomat: Professori: Perusterveyden-huollon romahtamisen syynä keikkalääkärit ja tietojärjestelmät (Professor: Reasons for collapse of primary healthcare are freelance doctors and information systems) (September 19, 2013), http: / /www.hs.fi/kotimaa/a1379554098791 (accessed January 5, 2014)

19. YLE (Finnish National Broadcasting Company) / Merja Niilola: Terveydenhuollon ithankinnoissa lähes kaikki mennyt pieleen (In healthcare IT procurement almost everything gone wrong) (May 21, 2012),

http://yle.fi/uutiset/terveydenhuollon_it-hankinnoissa_ lahes_kaikki_on_mennyt_pieleen/ 6103664 (accessed November 5, 2014)

20. YLE (Finnish National Broadcasting Company) IT-asiantuntija: Husin uusi potilastietojärjestelmä menossa pahasti pieleen (IT specialist: Hus' new patient information system going terribly wrong) (May 7, 2013),

http://yle.fi/uutiset/it-asiantuntija_husin_uusi_ potilastietojarjestelma_menossa_pahasti_pieleen/6630873 (accessed January 5, 2014)

21. Kivekäs, O.: Blog entry 8.6.2012: Epicfail, eli sairaaloiden IT eilen, tänään ja huomenna (Epic fail i.e. hospitals' IT yesterday, today and tomorrow) (2012),

http: //otsokivekas.fi/2012/06/epic-fail-eli-sairaaloiden-iteilen-tanaan-ja-huomenna/ (accessed January 5, 2014) 
22. Östman, K.: Blog entry: Potilastietojärjestelmät ja niiden hinta - tolkkua tuhlaukseen (Patient information systems and their costs - making sense in wasting money),

http://kimmoostman.blogit.hameensanomat.fi/2012/10/07/potila stietojarjestelmat-ja-niiden-hinta-tolkkua-tuhlaukseen/ (accessed January 5, 2014) (October 10, 2012)

23. Garets, D., Davies, M.: Electronic Patient Records EMRs and EHRs Concepts as different as apples and oranges at least deserve separate names. Healthcare Informatics (October 2005)

24. Hoidokki: Asiasanasto (Medical Subject Headings), Finnish Foundation of Nursing Education (2005-2014) (2014),

http://www.hoidokki.fi/index.php?MITform=sanat_aihe\&t=

5 \&aiheno=9 (accessed January 4, 2014)

25. City of Helsinki: What is the Apotti Program about? (2013),

http: / / www.hel.fi/hki/apotti/fi/Apotti-hanke/English

(accessed: January 3, 2014)

26. Valta, M.: Sähköisen potilastietojärjestelmän sosiotekninen käyttöönotto: seitsemän vuoden seurantatutkimus odotuksista omaksumiseen (The sociotechnical implementation of an electronic patient record. A seven-year follow-up study from expectations to adoption) Faculty of Social Sciences and Business Studies. Doctoral Thesis. Publications of the University of Eastern Finland. Dissertations in Social Sciences and Business Studies, no 62 (2013), http: / / urn. fi /URN : ISBN : 978-952-61-1217-6 (accessed: December 20, 2013)

27. Winbland, I., Hyppönen, H., Väskä, J., Reponen, J., Viitanen, J., Elovainio, M., Lääveri, T.: Potilastietojärjestelmät tuotemerkeittäin arvioitu: Kaikissa kehitettävää (Patient Information Systems evaluated by brand: All of them require improvement) Suomen Lääkärilehti (The Finnish Medical Journal) 50-52/2010 vsk 65 (2010)

28. Arvola, T., Pommelin, P., Inkinen, R., Väyrynen, S., Tammela, O.: Potilastietojärjestelmien turvallisuusriskit hallintaan (To control the securityrisks in patientinformationsystems) Suomen Lääkärilehti (Finnish Medical Journal) 12/2012 vsk 67 (2012)

29. Vuokko, R., Mäkelä, M., Komulainen, J., Meriläinen, O.: Terveydenhuollon toimintaprosessit: Terveydenhuollon yleiset prosessit ja niiden tarkennukset (The healthcare processes: general healthcare processes and their specifications) Raportti 53/2011, ISSN 1798-0089; ISBN 978-952-245-535-2 (pdf). Terveydenjahyvinvoinninlaitos (THL) (Finnish National Institute of health and wellfare), Helsinki (2011), http://www.thl.fi/thl-client/pdfs/f2fd2a43-4e9142e7-b7fe-5607f86e4d79 (accessed: December 20, 2013)

30. Koskinen, J., Heimo, O.I., Kimppa, K.K.: A viewpoint for more ethical approach in healthcare information system development and procurement: the four principles. In: The 4th International Conference on Well-being in the Information Society - Exploring the Abyss of Inequalities, Turku, Finland, August 22-24 (2012)

31. Heimo, O.I., Kimppa, K.K., Nurminen, M.I.: Ethics and the Inseparability Postulate - How to make better critical governmental information systems. In: ETHICOMP 2014 - - Liberty and Security in an Age of ICTs, Paris, France, June 25-27 (in print, 2014)

32. Heimo, O.I., Koskinen, J.S.S., Kimppa, K.K.: Responsibility in Acquiring Critical Governmental Information Systems: Whose Fault is Failure? In: ETHICOMP 2013 - The possibilities of ethical ICT, June 12-14. University of Southern Denmark, Kolding (2013)

33. Avison, D., Torkzadeh, G.: Information Systems Project Management. Saga Publications, California (2008) 
34. Fleischman, W.M.: Electronic Voting Systems and The Therac-25: What Have We Learned? In: ETHICOMP 2010 - The "Backwards, Forwards and Sideways" Changes of ICT, April 14-16. Universitat Rovirai Virgili, Tarragona (2010)

35. Mercuri, R.: Electronic Vote Tabulation: Checks and Balances. PhD thesis, University of Pennsylvania (2001), http: / / www. cis . upenn. edu/grad/documents / mercuri-r.pdf (accessed January 4, 2014)

36. Heimo, O.I., Fairweather, N., Ben, K., Kai, K.: The Finnish eVoting Experiment: What Went Wrong? In: ETHICOMP 2010 - The "Backwards, Forwards and Sideways" Changes of ICT, April 14-16. Universitat Rovirai Virgili, Tarragona (2010)

37. Robison, W.L.: Voting and Mix-And-Match Software. In: ETHICOMP 2010 - The "Backwards, Forwards and Sideways" Changes of ICT, April 14-16. Universitat Rovirai Virgili, Tarragona (2010)

38. Larsen, E., Ellingsen, G.: Facing the Lernaean Hydra: The Nature of Large-Scale Integration Projects in Healthcare. In: Kautz, K., Nielsen, P.A. (eds.) SCIS 2010. LNBIP, vol. 60, pp. 93-110. Springer, Heidelberg (2010)

39. Wijvertrouwenstemcomputersniet:Rop Gonggrijp, Willem-Jan Hengeveld - Studying the Nedap/Groenendaal ES3B voting computer, a computer security perspective. In: Proceedings of the USENIX Workshop on Accurate Electronic Voting Technology (2007),

http://wijvertrouwenstemcomputersniet.nl/images/c/ce/ES3B_ EVT07.pdf (accessed February 7, 2011) (see also

http://wijvertrouwenstemcomputersniet.nl/English

40. Verzola, R.: The Cost of Automating Elections (2008),

http: / /ssrn. com/abstract $=1150267$ (accessed January 4, 2014)

41. Heimo, O.I., Hakkala, A., Kimppa, K.K.: How to abuse biometric passport systems. Journal of Information, Communication and Ethics in Society 10(2), 68-81 (2012)

42. Aristotle, Nicomachean Ethics. Multiple translations

43. Danzon, P., Furukawa, M.: e-Health: Effects of the Internet on Competition and Productivity in Health Care. In: Internet, B.T.F. (ed.) The Economic Payoff from the Internet Revolution'. Brookings Institution Press, Washington DC (2001)

44. Mäkelä, K.: Terveydenhuollon tietotekniikka, terveyden ja hyvinvoinnin sovellukset (Health care information technology, health and welfare applications) Talentum Media Oy, Helsinki (2006)

45. Koskimies: Sairaalatietojärjestelmien historiaa (History of hospital information systems). In: Saranto, K., Korpela, M. (eds.) Tietotekniikka ja tiedonhallinta sosiaali- ja terveydenhuollossa, pp. 63-85. WSOY, Porvoo (1999)

46. Korpela, M., Saranto, K.: Peruskäsitteet,osa-alueet ja toimijat (Basic concepts, sectors and actors). In: Saranto, K., Korpela, M. (eds.) Tietotekniikka ja tiedonhallinta sosiaali- ja terveydenhuollossa (Information Technology and Information Management in Social and Health Care), pp. 18-44. WSOY, Porvoo (1999)

47. Pirttivaara, M.: Terveydenhuollon tietojärjestelmäinvestoinnit ja niiden arviointi - fokuksessa potilastietojärjestelmät (Healthcare information system investments and their evaluation - the focus on patient information systems). In: SITRAn selvityksiä 22, SITRA (2010)

48. Tolppanen, E.-M.: Elektroninen potilaskertomus (Electronic patient record). In: Saranto, K., Korpela, M. (eds.) Tietotekniikka ja tiedonhallinta sosiaali- ja terveydenhuollossa (Information Technology and Information Management in Social and Health Care), pp. 241-253. WSOY, Porvoo (1999)

49. City of Helsinki: APOTTI-hanke. Hankesuunnitelma (APOTTI Program. Programplan) ohjausryhmän hyväksymä versio (version approved by the steering group) (May 22, 2013), http://www.hel.fi/static/taske/apotti/ Apotti-hankesuunnitelma-versio-4.pdf (accessed: December 21, 2013) 